九州大学学術情報リポジトリ

Kyushu University Institutional Repository

\title{
Floral Induction by Dark Pre-Treatment in Non- Vernalized Winter Barley
}

Kim, E-Hun

Laboratory of Crop Science, Faculty of Agriculture, Kyushu University

Furuya, Tadahiko

Laboratory of Crop Science, Faculty of Agriculture, Kyushu University

Inouye, Jun

Laboratory of Crop Science, Faculty of Agriculture, Kyushu University

https://doi.org/10.5109/23657

出版情報：九州大学大学院農学研究院紀要. 22 (3)，pp.119-124，1978-07. Kyushu University バージョン：

権利関係 : 


\title{
Floral Induction by Dark Pre-Treatment in Non-Vernalized Winter Barley
}

\author{
E-Hun Kim*, Tadahiko Furuya and Jun Inouye *** $^{* *}$ \\ Laboratory of Crop Science, Faculty of Agriculture, \\ Kyushu University 46-01, Fukuoka 812 \\ (Received 0 ctober 5, 1977)
}

\begin{abstract}
Dark pre-treatment at early growth stage was found to induce the flowering of nonvernalized barley varieties irrespective their different thermal andphotoperiodic responsibility. The possibility that the promotive effect of dark pre-treatment and of vernalization is based on the different mechanism was suggested.
\end{abstract}

\section{INTRODUCTION}

It was reported previously that in certain winter barley varieties dark treatment preceded to long day condition can replace, nearly quantitatively, the vernalization effect (Inouye and Ito, 1968; Adachi et al., 1970).

In the present experiment, aseptic culture of barley plants was examined to compare the flowering induced by dark pre-treatment and vernalization.

\section{MATERIALS AND METHODS}

In most experiments Hordeum vulgare $c v$. Hashirihadaka was used since short day treatment can hardly replace the effect of vernalization (Hirano and Suge, 1963) although it requires 45 days of vernalization treatment under aseptic cultural condition (Adachi et al., 1970). This may be convenient to distinguish the dark effect from so called "short-day vernalization".

The basal culture medium was a modified White's solution. The medium consisted of $360 \mathrm{mg} \mathrm{MgSO}, 200 \mathrm{mg} \mathrm{Ca}\left(\mathrm{NO}_{3}\right)_{2}, 200 \mathrm{mg} \mathrm{Na} \mathrm{SO}_{4}, 80 \mathrm{mg} \mathrm{KNO}, 65 \mathrm{mg}$ $\mathrm{NaH}_{2} \mathrm{PO}_{4}, 1.5 \mathrm{mg} \mathrm{ZnSO}, 1.5 \mathrm{mg} \mathrm{H}_{3} \mathrm{BO}_{3}$, 1. $5 \mathrm{mg} \mathrm{KI}, 4 \mathrm{mg}$ Fe-citrate, $10 \mathrm{~g}$ sucrose, $7 \mathrm{~g}$ agar and $1,000 \mathrm{ml}$ deionized water. The $16 \times 250 \mathrm{~mm}$ test tubes which contain $10 \mathrm{ml}$ of the culture medium were nutoclaved at $1.0 \mathrm{~kg} / \mathrm{cm}^{2}$ for 20 minutes.

Well matured seeds in medium size were sterilized by immersing in $75 \%$ alcohol for 3 minutes then in $10 \%$ freshly prepared calcium hypochlorite solution for 20 minutes, and finally in $3 \%$ hydrogen peroxide for 20 minutes. Immediately after sterilization, two seeds were sown in each tube and the tubes were covered with paper to prevent the medium from drying. The tubes were kept at $25^{\circ} \mathrm{C}$ under darkness for 2 days before subjecting to various

* Present address : Department of Agriculture, Gangweon National University, Chuncheon. Korea 200.

** Present address : Institute of Tropical Agriculture. Kyushu University 13, Fukuoka 812. 
treatments. For dark treatment, the tubes were wrapped with light proof black papers. Vernalization was held at $5^{\circ} \mathrm{C}$. Dark pre-treatment and short day treatment ( 8 hours light and 16 hours dark) was carried out at $25^{\circ} \mathrm{C}$. After these treatment, plants were grown in the continuous artificial light at $25^{\circ} \mathrm{C}$. The light was obtained from fluorescent tubes, mercury lamps and incandescent lamps, and the light intensity was about 6,000 lux at plant level.

The number of leaves formed before the initiation of floral primordia, was used as a measure of the readiness to flower. Floral primordia was examined with a binocular microscope about four months after seeding. Each treatment consisted of about 20 tubes.

\section{RESULTS AND DISCUSSION}

Effect of dark p-e-treatment on floral induction of different barley varieties

Four barley varieties, Kinai No. 5, Akashinriki, Hashirihadaka and Kobinkatagi, with different thermal and photoperiodic hehaviours (Suge, 1961), were used. Seeds were planted on the medium and prcincubated at $25^{\circ} \mathrm{C}$ under darkness for 2 clays before incubated at $5^{\circ} \mathrm{C}$ or $25^{\circ} \mathrm{C}$ under darkness for 30 days in spring barlcys and for 45 days in winter barleys, and then subsequently grown under continuous light at $25^{\circ} \mathrm{C}$ for about three months (Table 1).

Floral initiation was promoted not only by vernalization $\left(5^{\circ} \mathrm{C}\right)$ but also by dark pre-treatment $\left(25^{\circ} \mathrm{C}\right)$ in all varieties, although the promoting effect was less in the latter. It is notable that not only Hashirihadaka but also Kobinkatagi responded to the dark pre-treatment although these two varieties are known to have quite different vernalized ability induced by short day, but have almost same vernalizing response induced by low temperature (Hirano

Table 1. Effects of vernalization and dark pre-treatment on floralinduction of four barley varieties.

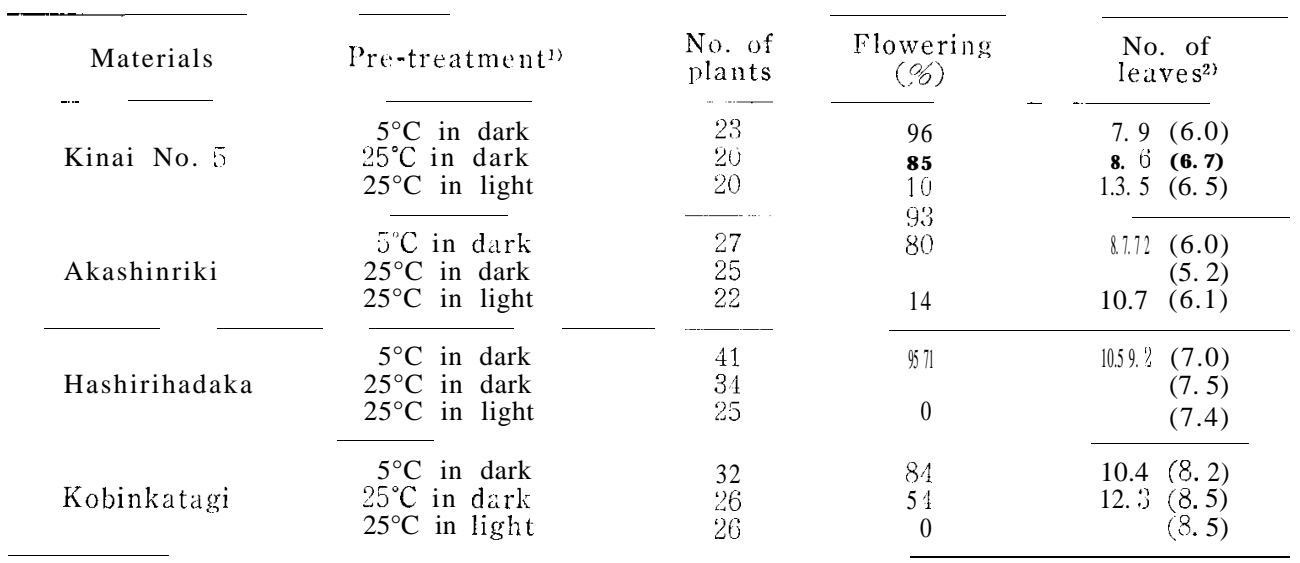

1) Duration of each treatment was 30 days in Kinai No. 5 and Akashinriki, and 45 days in Hashirihadaka and Kobinkatagi. ${ }^{2}$ Thenumber of leaves in plants without floral primordia is shown in parentheses. 
and Suge, 1963). The different degree of promotion between vernalization and dark pre-treatment was less in spring varieties than winter ones. Untreated control plants received no vernalization and no dark pre-treatment could not initiate floral primordia in winter varieties although about $15 \%$ of plants initiated floral primordia in spring varieties. These results suggest dark pretreatment is able to replace the vernalization in barley plants.

\section{Effect of sucrose on floral induction in dark pre-treatment}

Sufficient amount of sucrose in medium is indispensable for floral initiation of wheat and barley under total darkness (Sugino, 1957 ; Inouye and Ito, 1968). To examine the effect of different sucrose concentrations on floral induction, Hashirihadaka barley was cultured on media containing $0,1,3,5$ and $10 \%$ of sucrose, and subjected to $5^{\circ} \mathrm{C}$ or $25^{\circ} \mathrm{C}$ under darkness for 45 days. All plants were then grown under continuous light at $25^{\circ} \mathrm{C}$ (Table 2).

No difference was detected in all sucrose concentrations except vernalization induced by low temperature appeared to be more effective than dark pre-treatment. When plants were grown in medium' containing no sucrose, 20 $\%$ of vernalized plants initiated flowers at about 10 th node whereas all plants received only the dark pre-treatment died after about 5 leaves had developed. Control plants without vernalization or dark pre-treatment failed to initiate floral primordia irrespective of sucrose concentration. It is suggested that sucrose may play a role as an energy source for the growth during the dark pre-treatment but can not replace the triggering effect on floral induction.

Effect of durations of dark pre-treatment. short day and vernalization on floral induction

Effect of low temperature on flowering can be replaced by short day treat-

Table 2. Effect of sucrose on floral induction of Hashirihadaka winter barley in dark pre-treatment.

\begin{tabular}{|c|c|c|c|c|}
\hline Prc-treatment" & $\begin{array}{c}\text { Sucrose conc. } \\
(\%)\end{array}$ & $\begin{array}{l}\text { No. of } \\
\text { plants }\end{array}$ & $\begin{array}{c}\text { Flowering } \\
(\%)\end{array}$ & $\begin{array}{l}\text { No. of } \\
\text { leaves }\end{array}$ \\
\hline $5^{\circ} \mathrm{C}$ in dark & $\begin{array}{r}\mathbf{0} \\
1 \\
3 \\
5 \\
10\end{array}$ & $\begin{array}{l}23 \\
37 \\
37 \\
34 \\
41\end{array}$ & $\begin{array}{l}26 \\
92 \\
89 \\
94 \\
95\end{array}$ & $\begin{array}{r}10.3(6.8) \\
9.6(6.7) \\
9.7(6.5) \\
9.6(7.0) \\
9.5(8.0)\end{array}$ \\
\hline $25^{\circ} \mathrm{C}$ in dark & $\begin{array}{r}0 \\
1 \\
3 \\
5 \\
10\end{array}$ & $\begin{array}{l}22 \\
28 \\
38 \\
26 \\
26\end{array}$ & $\begin{array}{r}0 \\
57 \\
74 \\
50 \\
77\end{array}$ & $\begin{array}{rr} & (5.2) \\
9.8 & (7.6) \\
10.0 & (7.5) \\
10.2 & (6.9) \\
10.1 & (6.2)\end{array}$ \\
\hline $25^{\circ} \mathrm{C}$ in $\mathrm{light}$ & $\begin{array}{r}0 \\
1 \\
3 \\
5 \\
10\end{array}$ & $\begin{array}{r}16 \\
32 \\
17 \\
21 \\
9\end{array}$ & $\begin{array}{l}0 \\
0 \\
0 \\
0 \\
0\end{array}$ & $\begin{array}{r}(7.1) \\
(8.3) \\
(8.6) \\
(8.0) \\
(8.7)\end{array}$ \\
\hline
\end{tabular}

1) Duration of each treatment was 45 days. 2) The number of leaves in plants without floral primordia is shown in parentheses. 
Table 3. Effect of durations of dark pre-treatment, short day and vernalization on floral induction of Hashirihadaka winter barley.

\begin{tabular}{|c|c|c|c|c|}
\hline Pre-treatment & $\begin{array}{l}\text { Duration } \\
\text { in days }\end{array}$ & $\begin{array}{l}\text { No. of } \\
\text { plants }\end{array}$ & $\begin{array}{c}\text { Flowering } \\
(05)\end{array}$ & $\begin{array}{l}\text { No. of } \\
\text { leaves }\end{array}$ \\
\hline $\mathbf{5}^{\circ} \mathbf{C}$ in dark & $\begin{array}{l}15 \\
30 \\
45\end{array}$ & $\begin{array}{l}30 \\
40 \\
34\end{array}$ & $\begin{array}{l}43 \\
98 \\
94\end{array}$ & $\begin{array}{r}10.2(7.5) \\
9.2(7.0) \\
8.7(7.0)\end{array}$ \\
\hline $25^{\circ} \mathrm{C}$ in dark & $\begin{array}{l}15 \\
30 \\
45\end{array}$ & $\begin{array}{l}23 \\
30 \\
30\end{array}$ & $\begin{array}{r}9 \\
57 \\
80\end{array}$ & $\begin{array}{l}12.0(7.8) \\
11.5(8.5) \\
10.5(7.5)\end{array}$ \\
\hline Short day at $25^{\circ} \mathrm{C}^{\prime \prime}$ & $\begin{array}{l}15 \\
30 \\
45\end{array}$ & $\begin{array}{l}28 \\
24 \\
25\end{array}$ & $\begin{array}{l}0 \\
0 \\
0\end{array}$ & $\begin{array}{l}(7.8) \\
(7.4) \\
(6.8)\end{array}$ \\
\hline
\end{tabular}

ment in certain winter barley varieties (Suge, 1961 ; Chujo, 1962, 1975). Seeds of Hashirihadaka barley were sown on the medium and subjected to $5^{\circ} \mathrm{C}$ and $25^{\circ} \mathrm{C}$ under darkness or short day condition at $25^{\circ} \mathrm{C}$ for 15,30 and 45 days. Thereafter, they were grown under continuous light at $25^{\circ} \mathrm{C}$ (Table 3 ).

When treatments were given for 15 days, $43 \%$ of plants initiated floral primordia after vernalization whereas only $9 \%$ of plants initiated floral primordia after dark pre-treatment. Almost all plants received 30 or 45 days vernalization initiated floral primordia after having about 9 leaves. In the dark pre-treatment, flowering response increased gradually as the periods of the treatment were increased, and $80 \%$ of plants initiated floral primordia after having 10.5 leaves in the treatment of 45 days. However, floral initiation did not occur when the plants were subjected to short day treatment immediately after germination. It indicates the promotive effect of dark pre-treatment on floral induction is differed from the effect of short day treatment.

\section{Effect of seedling age prior to dark pre-treatment or vernalization on floral induction}

It is well known that vernalization of winter cereals can be advanced not only in immature seed stage on the mother plant or in germinating stage but also in early seedling stage (Purvis, 1961 ; Napp-Zinn, 1973). It is reported in winter wheat that the most favorable temperature for vernalization does not differ among different ages of seedling at the start of the treatment, although vernalizing effect decreased with increasing seedling age (Chujo, 1975). Seeds of Hashirihadaka were planted on medium and incubated at $25^{\circ} \mathrm{C}$ under darkness for 2 days. The germinated seeds were cultured first under continuous light at $25^{\circ} \mathrm{C}$ for $0,1,2,5$ and 10 days, and subsequently received vernalization under continuous light about 100 lux or dark pre-treatment for 45 days, respectively. Thereafter, they were grown under continuous light at $25^{\circ} \mathrm{C}$ for three months (Table 4).

All of vernalized plants initiated floral primordia irrespective of cultural 
Table 4. Effect of seedling age prior to dark pre-treatment or vernalization on floral induction of Hashirihadaka winter barley.

\begin{tabular}{|c|c|c|c|c|}
\hline \multirow[b]{2}{*}{ Pre-treatment } & \multirow[b]{2}{*}{$\begin{array}{l}\text { Number } \\
\text { of days" }\end{array}$} & & & \\
\hline & & $\begin{array}{l}\text { No. of } \\
\text { plants }\end{array}$ & $\begin{array}{c}\text { Flowering } \\
(\%)\end{array}$ & $\begin{array}{l}\text { No. of } \\
\text { leaves }\end{array}$ \\
\hline $5^{\circ} \mathrm{C}$ in dark & $\begin{array}{r}1 \\
2 \\
5 \\
10\end{array}$ & $\begin{array}{l}17 \\
24 \\
20 \\
\\
1614\end{array}$ & $\begin{array}{l}100 \\
100 \\
100100\end{array}$ & $\begin{array}{l}7.5 \\
8.0 \\
8.5\end{array}$ \\
\hline $25^{\circ} \mathrm{C}$ in dark & $\begin{array}{c}0 \\
1 \\
2 \\
5 \\
10\end{array}$ & $\begin{array}{l}28 \\
15 \\
18 \\
14 \\
14\end{array}$ & $\begin{array}{l}57 \\
47 \\
33 \\
36 \\
14\end{array}$ & $\begin{array}{rr}9.8 & (7.6) \\
10.3 & (6.9) \\
10.0 & (6.4) \\
10.4 & (6.3) \\
10.5 & (6.7)\end{array}$ \\
\hline
\end{tabular}

1) Days of cultivation at $25^{\circ} \mathrm{C}$ under continuous light prior to dark pre-treatment or vernalization. 2) The number of leaves in plants without floral primordia is shown in parentheses.

durations under continuous light prior to vernalization, although the number of leaves before initiation of floral primordia increased with increasing cultural durations prior to vernalization. On the other hand, flowering response in dark pre-treatment decreased gradually with increasing cultural durations prior to dark pre-treatment, and only $14 \%$ of plants initiated floral primordia in 10 days of culturing prior to dark pre-treatment. The difference in the promotive effects between vernalization and dark pre-treatment increased gradually as the cultural durations under continuous light before vernalization or dark pre-treatment were prolonged.

Effect of alternating treatment of vernalization and dark pre-treatment on floral induction

As shown in the above result, the dark pre-treatment was effective for floral initiation in non-vernalized plants, but flowering response was always less than that induced by vernalization. Therefore, alternative treatments of vernalization and dark pre-treatment on Hashirihadaka prior to continuous light were set up in order to examine the possible mechanism of floral induction caused by these two treatments (Table 5).

Maximum flowering response was obtained by vernalization under continuous light and followed by vernalization under darkness; next responses were obtained in the order that alternative vernalization in darkness and dark pre-treatment, dark pre-treatment, and untreated control. These results indicate that the dark pre-treatment can not fully replace vernalization in promoting floral induction. Furthermore, continuous light given during low temperature promoted floral induction under high temperature condition. The results presented here support that the floral induction caused by dark pretreatment and by vernalization is based on the different mechanisms. In dark condition, irrespective of temperature, barley plants may flower by their natural tendency to flower. 
Table 5. Effect of alternating treatment of vernalization and dark pretreatment on floral induction of Hashirihadaka winter barley.

\begin{tabular}{|c|c|c|c|}
\hline $\begin{array}{cccc}\text { Days } & \text { of } & \text { pre-treatment } \\
0 & 15 & 30 & 45\end{array}$ & $\begin{array}{l}\text { No. of } \\
\text { plants }\end{array}$ & $\begin{array}{c}\text { Flowering } \\
(\%)\end{array}$ & $\begin{array}{l}\text { No. of } \\
\text { leaves }{ }^{1)}\end{array}$ \\
\hline- & 17 & 100 & 7. 5 \\
\hline $\begin{array}{l}\because \therefore \quad \ldots \\
\end{array}$ & 15 & 53 & $8.8(7.0)$ \\
\hline$\square \square \quad \square \quad \square \quad \square$ & 22 & 91 & $9.7(7.5)$ \\
\hline$\square$ & 26 & 92 & 9.7 (7. 0) \\
\hline 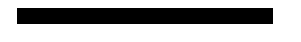 & 20 & 60 & $9.8 \quad(6.4)$ \\
\hline E & 23 & 0 & (6.2) \\
\hline
\end{tabular}

$55^{\circ} \mathrm{C}$ under continuous light; $55^{\circ} \mathrm{C}$ in darkness ;

$25^{\circ} \mathrm{C}$ in darkness ; and $25^{\circ} \mathrm{C}$ under continuous light (untreated control). 1) The number of leaves in plants without floral primordia is shown in parentheses.

\section{ACKNOWLEDGEMNET}

We wish to thank Dr. C. G. Kuo of the Asian Vegetable Research and Development Center, for his valuable advice in the preparation of the manuscript. We also thank Mrs. K. Akiyama of this laboratory for her assistance.

\section{REFERENCES}

Adachi, K., J. Inouye and K. Ito 1970 Flower initiation in total darkness in long-day plant, Hordeum vulgare L. var. mudum Hook f., winter naked barley. J. Fac. Agr. Kyushu Univ., 16: 77-84

Chujo, H. 1962 Studies in short day vernalization of barley. 3. Difference in short day vornalization effects as affected by temperature. Proc. Crop. Sci. Soc. Japan (in Japanese), 31: 150-154

Chujo, H. 1975 Studies of vernalization in wheat and barley plants, especially on effects of factors on the vernalization of growing plants. Bull. Univ. Osaka Pref. (in Japanese), Ser. B 27: $253-310$

Hirano, J. and H. Suge 1963 Physiology of heading in barley. III. Thermal and photoperiodic induction during seedling stage in winter barley. Jap.J. Breeding (in Japanese), 13: $42-47$

Inouye, J. and K. Ito 1968 Flower initiation in total darkness in long-day plant, Hordeum vulgare L. var. nudum Hook f. Plant \& Cell Physiol., 9: 137-142

Napp-Zinn, K. 1973 Low temperature effect on flower formation : Vernalization. In "Temperature and Life", ed. by H. Precht. J. Christophersen. H. Hensel and W. Larcher, Springer-Verlag. Berlin-Heiderberg-New York, pp. 171-194

Purvis, 0. N. 1961 The physiological analysis of vernalization. In "Handbuch der Pflanzenphysiologie", Bd. 16. ed. by W. Ruhland, Springer-Verlag, Berlin-Göttingen-Heiderberg, pp. 76-133

Suge, H. 1961 Physiology of heading in barley. II. Effect of pre-treatment with different temperature and photoperiod to heading behaviour. Jap. J. Breeding (in Japanese), 11: $10-18$

Sugino, M. 1957 Flower initiation of the spring wheat in total darkness. Bot. Mag. Tokyo, $70: 369-375$ 